\title{
Dentin Matrix Acidic Phosphoprotein 1
}

National Cancer Institute

\section{Source}

National Cancer Institute. Dentin Matrix Acidic Phosphoprotein 1. NCI Thesaurus. Code C95577.

Dentin matrix acidic phosphoprotein 1 (513 aa, $~ 56 \mathrm{kDa}$ ) is encoded by the human DMP1 gene. This protein plays a role in the activation of osteoblast-specific genes and the nucleation of hydroxyapatite. 